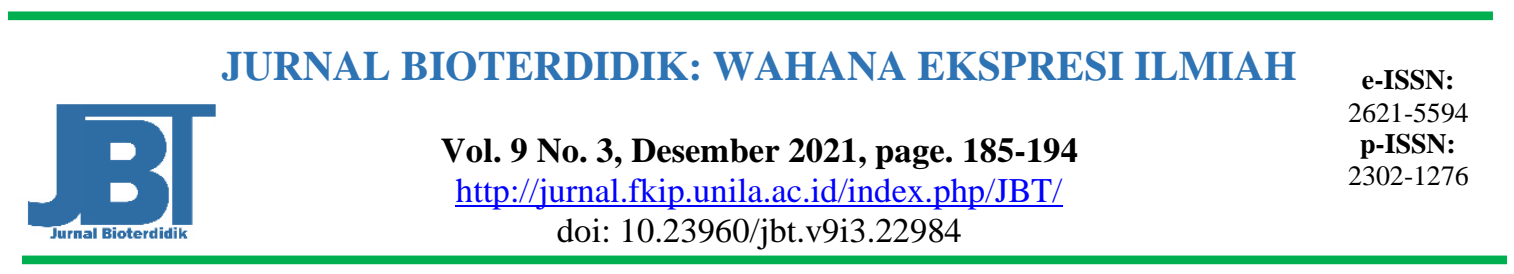

\title{
Uji Kelayakan Panduan Praktikum Keragaman Genetik Menggunakan Model Project Based Learning
}

\author{
Maheni Maheni, Jodion Siburian, Evita Anggreini \\ Pendidikan Biologi, Fakultas Keguruan dan Ilmu Pendidikan, Universitas Jambi, Indonesia \\ *email: jodion.siburian@unja.ac.id
}

Abstract: Feasibility Test of Genetic Diversity Practicum Guide Using Project Based Learning Model. Aims to produce a proper practicum guide based on the aspects of the validity of the material and media. The research data was collected using the ADDIE model. The results of the study focused on the data of the development stage. The data obtained were analyzed qualitatively in the form of suggestions from the validator and quantitative analysis in the form of a Likert scale questionnaire. Research in the development stage uses an instrument, namely a material and media expert validation questionnaire sheet. Based on the results of the study, it was found that the practicum guide product developed was declared feasible in terms of the validity of the material and media, with a percentage score of $94 \%$ and $86 \%$ in the very good category. The results of the trial showed that in the small group trial $80 \%$ (good) and the large group trial $87 \%$ (very good).

Keywords: project based learning, genetic diversity, practical guide

\begin{abstract}
Abstrak: Uji Kelayakan Panduan Praktikum Genetika Keragaman Genetik Menggunakan Model Project Based Learning. Bertujuan menghasilkan panduan praktikum yang layak berdasarkan aspek kevalidan materi dan media. Data penelitian dihimpun menggunakan model ADDIE. Hasil penelitian difokuskan pada data tahap development. Data yang diperoleh dianalisis secara kualitatif berupa saran dari validator dan analisis kuantitatif berupa angket skala likert. Penelitian tahap development menggunakan instrumen yaitu lembar angket validasi ahli materi dan media. Berdasarkan hasil penelitian didapatkan bahwa produk panduan praktikum yang dikembangkan dinyatakan layak dalam aspek kevalidan materi dan media, dengan skor persentase yaitu 94\% dan 86\% kategori sangat baik. Hasil ujicoba didapatkan bahwa pada ujicoba kelompok kecil 80\% (baik) dan ujicoba kelompok besar 87\% (sangat baik).
\end{abstract}

Kata kunci: keragaman genetik, panduan praktikum, project based learning 


\section{PENDAHULUAN}

Panduan praktikum memegang peranan penting untuk mencapai keberhasilan suatu praktikum. Panduan praktikum adalah petunjuk dalam melakukan praktikum yang memuat persiapan praktikum, tahapan praktikum, analisis data dan format laporan sesuai dengan aturan penulisan ilmiah yang disusun oleh praktikan (Nurussaniah \& Nurhayati, 2016). Panduan praktikum merupakan pedoman mahasiswa dalam menguji dan melaksanakan secara nyata sesuatu yang diperoleh berupa konsep dari teori (Lauren, dkk, 2016). Panduan praktikum yang layak menuntun mahasiswa dalam memahami kegiatan praktikum berisikan judul dan tujuan praktikum, materi, daftar alat dan bahan, tahapan pelaksanaan praktikum, format hasil, pertanyaan pasca praktikum, kesimpulan, dan daftar pustaka (Nursapikka, 2017). Oleh karena itu, panduan praktikum perlu dibuat guna memperlancar dan menuntun mahasiswa dalam memahami pelaksanaan kegiatan praktikum.

Panduan praktikum berfungsi sebagai bahan ajar dalam bentuk media visual. Mahasiswa dapat belajar lebih aktif dan kreatif dari bahan ajar dan pengalaman nyata. Menurut Nursapikka (2017) bahwa panduan praktikum berperan sebagai media berbasis visual yang sangat penting dalam proses belajar. Menurut Hidayaturrahman (2018) panduan praktikum berfungsi sebagai bahan ajar yang dapat menjadikan mahasiswa semakin aktif. Dari pengalaman nyata mahasiswa juga mendorongnya menjadi lebih kreatif (Suwarno \& Hasanudin, 2020).

Panduan yang digunakan pada praktikum genetika di Pendidikan Biologi Universitas Jambi belum memuat materi keragaman genetik. Menurut Erwinsyah \& Nurjhani (2016) bahwa materi keragaman genetik perlu ditambahkan ke dalam kegiatan praktikum. Hal ini karena materi mengenai keragaman ini penting untuk menunjukkan variasi genetik yang ada pada makhluk hidup. Sejalan dengan itu, berdasarkan penyebaran angket pendahuluan kepada 31 mahasiswa Pendidikan Biologi Universitas Jambi angkatan 2018. Data yang didapatkan yaitu sebanyak 61\% mahasiswa sangat setuju, jika materi keragaman genetik di tambahkan pada kegiatan praktikum genetika. Serta didukung oleh capaian pembelajaran ranah pengetahuan pada materi keragaman genetik. Capaian pembelajaran pada materi ini yaitu mahasiswa mampu membuktikan keragaman genetik pada hewan melalui pengamatan fenotip dan membandingkan ciri-ciri yang berbeda untuk sifat tertentu pada hewan yang ada dilingkungan sekitar tempat tinggal praktikan.

Pelaksanaan praktikum selama ini tidak berjalan mulus. Pelaksanaan praktikum memiliki beberapa kendala. Berdasarkan angket studi pendahuluan yang diisi oleh 31 orang yang telah mengontrak mata kuliah genetika, bahwa 55\% mahasiswa mengalami kendala berupa keterbatasan waktu, 68\% praktikum terfokus pada penuntun, $55 \%$ mahasiswa berpendapat praktikum kurang dikaitkan dengan kehidupan nyata. Maka, untuk mengatasi kendala tersebut dilakukan pengembangan panduan praktikum materi keragaman genetik menggunakan model yang cocok.

Model yang cocok diterapkan pada pengembangan panduan praktikum materi keragaman genetik yaitu model Project Based Learning (PjBL). Penggunaan PjBL akan membuat panduan praktikum lebih menarik, bermakna, dan dapat meningkatkan kemampuan berpikir kreatif mahasiswa. Penyebabnya karena model ini menuntut mahasiswa untuk memecahkan masalah melalui proyek yang dikerjakan mahasiswa secara langsung, waktu yang fleksibel. Hal ini sesuai dengan Mukhtar, dkk (2015) bahwa panduan praktikum PjBL pada implementasinya menuntut mahasiswa untuk mentukan alat dan bahan sendiri atau secara berkelompok. Selain itu menurut Usman \& Ratnasari, 
(2019) proyeknya memuat tugas yang kompleks berdasarkan pada permasalahan yang sangat menantang. Menurut Suwarno \& Hasanudin, (2020) bahwa model PjBL diarahkan agar mahasiswa belajar dari pengalaman nyata yang mendorong mahasiswa menjadi lebih kreatif.

Pengembangan panduan praktikum dilakukan menggunakan model ADDIE. Tahap development pada penelitian merupakan tahapan penting. Alasannya, karena pada tahap development, panduan praktikum yang sudah dirancang wajib melewati proses validasi produk untuk diuji kelayakannya. Validasi produk dilakukan oleh dosen ahli materi dan media. Penelitian ini bertujuan untuk menghasilkan panduan praktikum materi keragaman genetik menggunakan model Project Based Learning yang layak berdasarkan aspek materi dan media.

\section{METODE}

Metode yang digunakan adalah penelitian pengembangan. Pelaksanaan penelitian pengembangan panduan praktikum materi keragaman genetik menggunakan model Project Based Learning. Jenis penelitian pengembangan yang digunakan adalah ADDIE. Ada lima langkah utama pada model ini yaitu: Analysis, Design, Development, Implentation, dan Evaluation (Branch \& Gustafson, 2009). Penelitian ini difokuskan untuk mengkaji tahap Development. Tahap Development merupakan langkah awal perbaikan produk rancangan panduan pratikum. Perbaikan dilakukan atas dasar saran dari hasil angket validasi oleh ahli materi, media dan hasil angket respon mahasiswa. Instrumen penelitian pada tahap Development yaitu lembar angket validasi ahli materi, lembar angket validasi media dan lembar angket respon mahasiswa.

Proses validasi dilakukan dengan menyebar angket validasi kepada ahli materi dan ahli media. Hasil angket dianalisis menggunakan analisis deskriptif kualitatif dan kuantitatif. Analisis deskriptif kualitatif bersumber dari saran, kritik dan komentar oleh validator ahli materi dan media pada lembar angket validasi. Sedangkan analisis statistik deskriptif mencakup penilaian keseluruhan aspek. Data kuantitatif bersumber dari data jumlah poin yang didapat dari angket validasi. Lalu, data diukur menggunakan skala likert dengan skor 1-5. Skor 1 memiliki arti sangat tidak baik, skor 2 berarti tidak baik, skor 3 berarti kurang baik, skor 4 berarti baik dan skor 5 berarti sangat baik (Sugiyono, 2018). Hasil dari lembar angket validasi dihitung skor totalnya. Kemudian, data akan dikonversi dalam bentuk persentase menggunakan rumus sebagai berikut:

$$
\text { Kevalidan }=\frac{\text { Jumlah skor yang diperoleh }}{\text { Jumlah skor masksimum }} \times 100 \%
$$

Setelah itu, data di klasifikasikan sesuai tabel kelayakan media berikut:

Tabel 1. Klasifikasi Kelayakan Media (Riduwan \& Akdon, 2020)

\begin{tabular}{ll}
\hline Skor Presentase (\%) & Klasifikasi \\
\hline $80-100$ & Sangat Baik (SB) \\
$60-80$ & Baik (B) \\
$40-60$ & Cukup Baik (CB) \\
$20-40$ & Tidak Baik (TB) \\
$0-20$ & Sangat Tidak Baik (STB) \\
\hline
\end{tabular}

Produk yang telah divalidasi, selanjutnya dilakukan uji coba. Uji coba terdiri dari uji coba kelompok kecil dan uji coba kelompok besar. Uji coba ini menggunakan 
instrument angket respon. Penyebaran angket respon dilakukan secara online melalui link google form. Uji coba kelompok kecil dilakukan pada 6 mahasiswa. Sedangkan uji coba kelompok besar dilakukan pada 15 mahasiswa. Mahasiswa yang menjadi responden pada tahap uji coba merupakan mahasiswa Pendidikan Biologi Universitas Jambi yang telah mengikuti mata kuliah dan praktikum genetika. Respons mahasiswa terhadap panduan praktikum yang dikembangkan dianalisis menggunakan analisis statistik deskriptif. Adapun saran yang diberikan akan diperhitungkan untuk digunakan sebagai acuan revisi. Hasil revisi merupakan produk akhir.

\section{HASIL DAN PEMBAHASAN}

Hasil pengembangan panduan praktikum keragaman genetik menggunakan model $P j B L$ terdiri dari beberapa komponen. Berikut merupakan komponen dari panduan yaitu bagian awal, isi dan akhir. Bagian awal terdiri dari cover depan, lembar editor, kata pengantar, daftar isi, daftar gambar dan tata tertib. Bagian isi terdiri atas capaian pembelajaran, panduan praktikum, tujuan praktikum, rumusan masalah, materi keragaman genetik, pelatihan keterampilan, tema proyek, jadwal proyek, pelaksanaan proyek dan evaluasi. Pada bagian isi ini terdapat fitur seperti kolom "Wow Fakta", kolom "Kata Kunci", kolom "Info Update". Bagian penutup terdiri atas evaluasi, daftar rujukan dan cover belakang. Hal ini sejalan dengan pendapatnya Nursapikka (2017) bahwa panduan praktikum yang layak berisikan judul dan tujuan praktikum, materi, daftar alat dan bahan, langkah praktikum, pertanyaan pasca, kesimpulan, dan daftar rujukan. Panduan ini dibuat disertai gambar-gambar, contoh dan informasi up to date yang diharapkan dapat membantu mahasiswa dalam melaksanakan praktikum keragaman genetik.

Panduan praktikum melalui proses validasi yang melibatkan dosen ahli materi dan ahli media. Tujuan adanya validasi produk ini adalah agar produk yang dikembangkan layak di ujicobakan kepada mahasiswa. Proses validasi materi dilakukan oleh ibu Winda Dwi Kartika, S.Si., M.Si. Sedangkan validasi media dilakukan oleh bapak Ali Sadikin, S.Pd.I., M.Pd. Validasi produk dari aspek materi maupun media dilakukan beberapa kali hingga mendapatkan produk yang layak. Produk yang layak memiliki beberapa kriteria, salah satunya yaitu aspek kevalidan (Alexander dkk, 2018).

Validasi produk aspek materi dilakukan tiga kali. Sedangkan validasi produk aspek media dilakukan dua kali. Kelayakan produk diketahui dari hasil penilaian masingmasing validator yang dikalkulasikan persentasenya secara menyeluruh. Sedangkan kelayakan setiap aspek panduan praktikum diketahui dari hasil perhitungan persentase masing-masing aspek validasi. Berdasarkan pengisian instrument angket yang didapat selama proses validasi materi dan media yang dilakukan secara keseluruhan, maka di dapatkan hasil pada Tabel 2.

Tabel 2. Hasil Pengisian Angket Validasi

\begin{tabular}{llcl}
\hline No & Jenis Validasi & Skor Presentase & Klasifikasi \\
\hline 1 & Validasi Materi I & $40 \%$ & Tidak Baik (TB) \\
2 & Validasi Materi II & $79 \%$ & Baik (B) \\
3 & Validasi Materi III & $94 \%$ & Sangat Baik (SB) \\
4 & Validasi Media I & $75 \%$ & Baik (B) \\
5 & Validasi Media II & $86 \%$ & Sangat Baik (SB) \\
\hline
\end{tabular}


Kelayakan isi, kelayakan penyajian dan kelayakan bahasa merupakan aspek yang dilihat dari proses validasi materi. Proses validasi materi dilakukan sebanyak tiga kali. Berdasarkan hasil validasi materi tahap pertama didapatkan persentase $40 \%$ yang termasuk kategori "tidak baik" dengan saran yaitu pada aspek kelayakan isi, panduan praktikum yang dibuat belum berdasarkan RPS, cakupan materi masih melebar, materi belum terkonsep, belum ada contoh yang relevan, materi belum up to date, panduan belum menggunakan tahap $\mathrm{PjBL}$, prosedur belum akurat, tata tertib belum fleksibel. Perbaikan aspek kelayakan isi dilakukan. Disesuaikan dengan Susantini, dkk (2012) bahwa aspek kelayakan isi ditinjau dari keluasan, kedalaman dan kebenaran konsep.

Pada aspek kelayakan penyajian, penyajian materi belum mengerucut dan belum memuat tahapan $\mathrm{PjBL}$, penyajian belum bervariasi, soal pasca praktikum masih terlalu sederhana, sumber gambar belum ada, kalimat pada wow fakta dan info update masih membingungkan, kata pengantar belum memuat tujuan adanya praktikum, belum ada capaian pembelajaran, info update, tahap pelaksanaan proyek dan evaluasi, daftar isi belum otomatis, tata letak gambar, ada sumber yang tidak relevan. Menurut Rismawati, dkk (2015) bahwa kelengkapan penyajian menunjukkan adanya bagian isi, pendahuluan, dan penutup pada media yang dikembangkan

Aspek kelayakan bahasa, informasi yang disajikan tidak menarik dan bahasa yang digunakan membingungkan, bahasa sulit dipahami, tata bahasa belum benar, dan ejaan belum sesuai dengan EYD. Hal ini seperti yang dikemukakan oleh Prastowo (2012) yaitu penggunaan kalimat sesederhana dan sesingkat mungkin, namun tetap jelas arah nya dan komunikatif, serta sertakan juga gambar pendukung materi. Pada tahap I masih terdapat sangat banyak yang harus diperbaiki. Maka dilakukan perbaikan mengikuti komentar dan masukan dari ahli materi.

Skor validasi panduan praktikum pada tahap II mengalami peningkatan secara signifikan. Peningkatan ini terjadi karena telah dilakukan revisi mengikuti dari masukan ahli materi. Namun masih memiliki kesalahan sehingga perlu dilakukan perbaikan kembali. Hasil validasi kedua panduan praktikum mendapat skor 79\% dengan klasifikasi "baik". Perbaikan kembali dilakukan, kali ini ditekankan pada tahapan praktikum, redaksi kalimat dan kalimat efektif. Menurut Sari dkk (2018) panduan praktikum yang ideal atau baik tidak membingungkan mahasiswa, baik dengan redaksi kalimat atau dengan apa yang harus dilakukan.

Saran yang diberikan oleh validator materi kedua yaitu pada aspek kelayakan isi, cakupan materi masih terlalu luas, fakta dan contoh belum sesuai dengan keadaan, tahap pelaksanaan dan evaluasi dimasukkan, tambahkan link jurnal diakhir info update, beberapa tata tertib masih belum fleksibel. Pada aspek kelayakan penyajian, meteri telah mengerucut namun masih membingungkan, soal pasca belum sesuai dengan tingkat mahasiswa, keterangan gambar diperbaiki, jabarkan contoh pada info update, komponen isi telah lengkap namun redaksi kalimat masih membingungkan. Pada aspek kelayakan bahasa, kalimat telah mengerucut namun belum menarik, tata kalimat sudah baik namun beberapa masih perlu perbaikan. Maka, dilakukan perbaikan sesuai saran validator. 
Akhirnya pada validasi materi ketiga skor presentase secara keseluruhan mengalami peningkatan menjadi 94\% termasuk klasifikasi "sangat baik. Namun, masih terdapat saran perbaikan diantaranya pada aspek kelayakan isi, tambahkan tentang fenotipe pada materi. Aspek kelayakan penyajian, soal pasca praktikum dilengkapi dengan contoh dan soal kedua lebih cocok menanyakan pengaruh. Sedangkan untuk aspek kelayakan bahasa sudah baik. Panduan praktikum diperbaiki sesuai dengan saransaran validator materi. Setalah diperbaiki, maka panduan praktikum disetujui untuk dilanjutkan pada tahap berikutnya. Berikut tabel persentase aspek validasi materi.

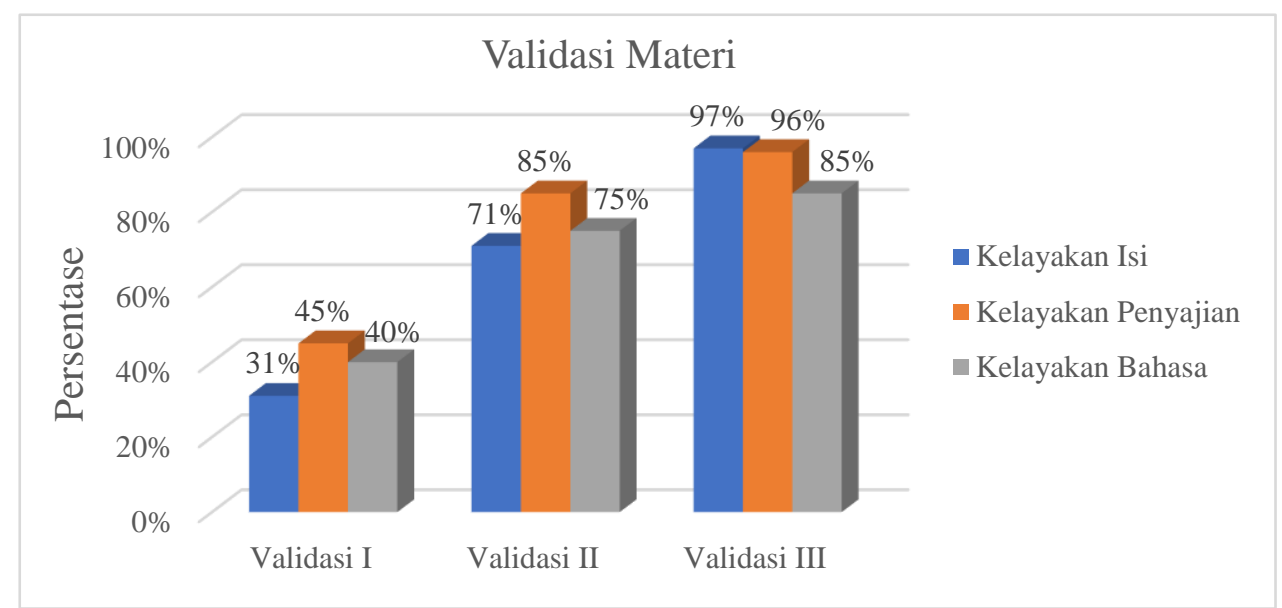

Gambar 1. Grafik Hasil Persentase Proses Validasi Materi

Selanjutnya tahap validasi produk oleh dosen ahli media sebanyak dua kali dengan persentase hasil validasi media tahap 1 yaitu $75 \%$ dengan klasifikasi "baik". Karena panduan praktikum yang dibuat telah sesuai dengan aspek pada angket yang diberikan, walau ada beberapa hal yang perlu diperbaiki. Saran perbaikan dari validator media berdasarkan aspek kualitas teknis diantaranya yaitu mengganti jenis dan jarak huruf pada cover depan, resolusi gambar sampul depan jangan pecah, tambahkan lembar editor, perbaiki kombinasi warna sampul, tambahkan jenis huruf lagi, pilih warna symbol kunci dan atur jarak spasi.

Hal ini sesuai dengan Safitri \& Hartati (2016) bahwa validasi media yang dilakukan pada panduan praktikum meliputi jenis huruf yang konsisten, kualitas gambar dan keterangannya. Selain itu, Hastika, dkk (2019) menyatakan bahwa kualitas gambar yang baik juga diperlukan agar dapat memperjelas dan menarik minat siswa pada kegiatan praktikum. Maka, dilakukan perbaikan sesuai saran dari validator media. Angket validasi media panduan praktikum terdiri dari aspek kualitas teknis. Berikut ini merupakan persentase aspek dari validasi media: 


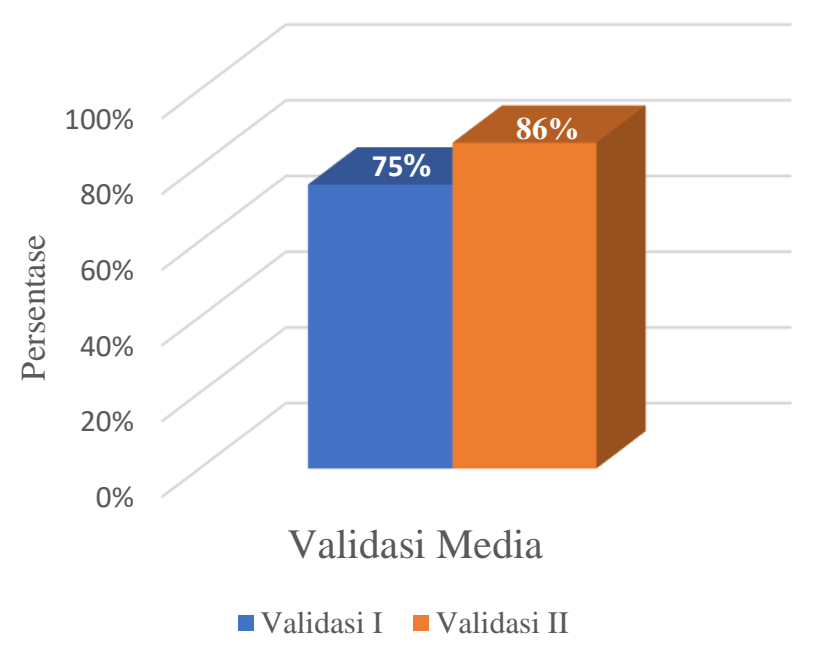

Gambar 2. Grafik Persentase Hasil Validasi Ahli Media

Setelah dilakukan perbaikan sesuai saran validator media, maka pada pertemuan selanjutnya skor angket mengalami peningkatan. Skor hasil yang didapat yaitu $86 \%$ (sangat baik). Pada tahap II validasi pada media, panduan praktikum yang dibuat valid dan telah layak untuk diuji cobakan serta tidak ada lagi yang perlu diperbaiki. Hal ini didukung oleh pernyataan Yerimadesi, dkk (2018) bahwa revisi selesai jika validator telah menyatakan bahwa modul yang dikembangkan valid. Sehingga dapat dilanjutkan kepada tahap berikutnya yaitu uji coba produk kepada mahasiswa.

Panduan praktikum keragaman genetik menggunakan model Project Based Learning dinyatakan layak dengan skor $94 \%$ pada aspek materi dan $86 \%$ untuk aspek media.yang mana termasuk klasifikasi sangat baik. Sesuai dengan pendapatnya Arikunto (2018) bahwa jika produk pengembangan telah valid dan layak, maka dapat dikatakan bahwa produk tersebut telah memberikan gambaran secara benar dan sesuai dengan keadaan sesungguhnya. Sesuai dengan hasil penelitiannya Lauren, dkk (2016) bahwa ia mendapatkan hasil yang positif dalam uji kelayakan dengan validasi, maka panduan praktikum layak dengan kategori sangat baik dapat digunakan pada praktikum genetika.

Panduan praktikum yang dikembangkan berkualitas. Penyebabnya karena panduan praktikum yang dikembangkan mengalami validitas uji kelayakan berbantukan angket validasi kepada dosen ahli materi dan ahli media. Pernyataan ini diperkuat oleh Nursamsu dkk (2020) bahwa modul praktikum sebagai perangkat pembelajaran dikatakan berkualitas, jika memenuhi syarat yaitu: jika validitas dilakukan dengan uji kelayakan modul praktikum dan validasi modul praktikum dilakukan dengan memberikan draf modul praktikum dan angket kepada 2 dosen ahli materi dan ahli desain.

Setelah panduan praktikum keragaman genetik menggunakan model Project Based Learning dinyatakan layak oleh validator maka dilanjutkan pada tahap implementasi. Produk diberikan kepada mahasiswa Pendidikan Biologi Universitas Jambi Angkatan 2018 untuk dilakukan ujicoba. Ujicoba produk terdiri atas 2, yaitu uji coba kelompok kecil dan uji coba kelompok besar. Uji coba kelompok kecil terdiri dari 6 mahasiswa dan kelompok besar terdiri dari 15 mahasiswa. Ujicoba produk dilakukan melalui penyebaran angket respon mahasiswa melalui google form. Tujuannya untuk mengetahui pendapat dan saran mahasiswa terhadap produk panduan praktikum.

Panduan praktikum keragaman genetik menggunakan model Project Based Learning yang dikembangkan pada uji coba kelompok kecil mendapat kategori "Baik" 
dengan persentase $80 \%$. Terdapat saran-saran yang diberikan oleh mahasiswa, sehingga perlu dilakukan perbaikan. Saran dari mahasiswa diantaranya yaitu penambahan format laporan berupa margin dan font, perbaikan penulisan link pada info update dan konsistensi jarak dan ukuran antar icon. Maka dilakukan perbaikan sesuai saran dari mahasiswa.

Uji coba kelompok besar mendapatkan persentase 87\% "Sangat Baik" tanpa ada yang harus direvisi. Menurut mahasiswa didapatkan bahwa panduan praktikum keragaman genetik yang dikembangkan sudah baik sehingga praktikan dapat melaksanakan praktikum secara mandiri.Materi praktikum menarik karena penggunaan Bahasa yang mudah dimengerti, ditambah dengan uraian dan gambar. Prosedur pengamatan juga jelas dan memudahkan praktikan dalam memahami materi serta melaksanakan praktikum. Berikut rata-rata respon kelompok kecil dan kelompok besar:

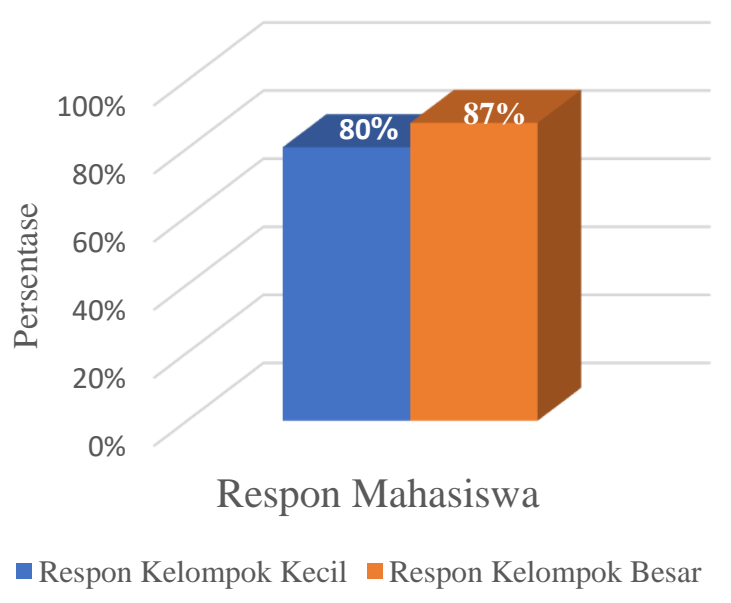

Gambar 3. Rata-rata Ujicoba Kecil dan Kelompok Besar

Berdasarkan hasil analisis ini, maka panduan praktikum keragaman genetik yang dikembangkan sudah layak digunakan dalam praktikum genetika. Hal ini diperkuat oleh pernyataan Weldan (2018) bahwa penuntun praktikum yang dikembangkan pada tahap uji coba produk menunjukkan respons siswa terhadap penuntun praktikum mendapatkan respons yang sangat tinggi dari siswa dengan rata-rata presentase $81,36 \%$ sehingga dapat dijadikan sebagai bahan ajar yang baik pada pembelajaran.

\section{SIMPULAN}

Berdasarkan hasil dan pembahasan penelitian pengembangan panduan praktikum keragaman genetik menggunakan model Project Based Learning, disimpulkan yaitu: Panduan praktikum yang dikembangkan dinyatakan sudah layak digunakan. Dikatakan layak karena memperoleh skor persentase dari ahli materi yaitu 94\% (sangat baik) dan memperoleh skor persentase dari ahli media 86\% (sangat baik). Hasil ujicoba kelompok kecil $80 \%$ kategori baik dan ujicoba kelompok besar $87 \%$ kategori sangat baik.

\section{DAFTAR RUJUKAN}

Alexander, A., Rahayu, H. M., \& Kurniawan, A. D. (2018). Pengembangan Penuntun Praktikum Fotosintesis Berbasis Audio Visual Menggunakan Program Camtacia Studio di SMAN 1 Hulu Gurung. Jurnal Pendidikan Sains Indonesia, 06(02), 75- 
82. https://doi.org/10.24815/jpsi.v6i2.12075

Arikunto, S. (2018). Prosedur Penelitian. Jakarta: Rineka Cipta.

Branch, R. M., \& Gustafson, K. (2009). Design Approaches and Tools in Education and Training (1st ed.). U.S.A: Kluwer Academic Publishers.

Erwinsyah, R., \& Nurjhani, M. (2016). Relevansi Praktikum Dan Perkuliahan Teori Pada Mata Kuliah Genetika Relevance Lab Activities And Lecturing Theory In Genetics Course. Proceeding Biology Education Conference, 13 (1), 546-553.

Hastika, W. D., Daningsih, E., \& Marlina, R. (2019). Kelayakan Penuntun Praktikum Submateri Struktur Dan Fungsi Jaringan Tumbuhan Dengan Tambahan Metode Replika. Jurnal Pendidikam Dan Pembelajaran Khatulistiwa, 8(2), 1-8.

Hidayaturrahman. (2018). Pengembangan Penuntun Praktikum Fisika Dasar I Berbasis Keterampilan Proses Sains dengan Menggunakan Model Pembelajaran Cooperative Learning Tipe Group Investigation pada Materi Pengukuran Mata Kuliah Fisika Dasar I. In Skripsi. Jambi: Universitas Jambi.

Lauren, I., Harahap, F., \& Gultom, T. (2016). Uji Kelayakan Penuntun Praktikum Genetika Berbasis Keterampilan Proses Sains Berdasarkan Ahli Materi dan Ahli Desain. Jurnal Pendidikan Biologi, 6(1), 206-212. https://doi.org/10.24114/jpb.v6i1.4322

Linda, C., Widodo, S., Karimah, N., \& Ngazizah, N. (2019). Penerapan Project Based Learning Pada Praktikum Mahasiswa PGSD Semester 2 untuk Meningkatkan Kreativitas dan Pemecahan Masalah. Jurnal Urecol, 1(2), 214-222.

Mukhtar, Z., Emiliya, R., \& Silaban, R. (2015). Pengembangan Penuntun Praktikum Model Discovery dan Project Based Learning pada pembelajaran Asam dan Basa di SMA Kelas XI. Jurnal Tabularasa PPS UNIMED, 12(3), 294-304.

Nursamsu, Mustika, D., R., N., \& Manurun N. (2020). Analisis Kelayakan Dan Kepraktisan Modul Praktikum Berbasis Literasi Sains Untuk Pembelajaran Ipa. Jipi (Jurnal Ipa Dan Pembelajaran Ipa), 4(1), 29-40.

Nursapikka, E. (2017). Kelayakan Penuntun Praktikum pada Sub Materi Peran Tumbuhan di Bidang Ekonomi Kelas X SMA. Artikel Penelitian.

Nurussaniah, \& Nurhayati. (2016). Pengembangan Penuntun Praktikum Fisika Dasar 1 Berbasis Guided Inquiry untuk Meningkatkan Kemampuan Berpikir Kritis Mahasiswa. (E-Journal) SNF, 5, 63-68.

Prastowo, A. (2012). Panduan Kreatif Membuat Bahan Ajar Inovatof. Yogyakarta: Diva Pres.

Riduwan, \& Akdon. (2020). Rumus dan Data dalam Analisis Statistika. Bandung: Alfabeta.

Rismawati, E., Widodo, M., \& Agustina, E. S. (2015). Kelayakan Penyajian Buku Teks Mahir Berbahasa Indonesia Kelas VII SMP/MTS Kurikulum 2013. Jurnal Kata (Bahasa, Sastra, Dan Pembelajarannya), 3(5), 1-10.

Safitri, D., \& Hartati, T. A. W. (2016). Kelayakan Aspek Media, dan Bahasa Dalam Pengembangan Buku Ajar dan Multimedia Interaktif Biologi Sel. Florea, 3(2), 914. https://doi.org/10.1093/oseo/instance.00168128

Saputra, O., Nurjannah, \& Mansyur, J. (2014). Pengaruh Problem-Based Learning Menggunakan Praktikum Alat Sederhana Pengaruh Problem-Based Learning Menggunakan Praktikum Alat Sederhana Terhadap Keterampilan Berpikir Kreatif Siswa SMA Negeri 7 Palu. Jurnal Pendidikan Fisika Tadulako, 2(2), 36-42. https://doi.org/10.22487/j25805924.2014.v2.i2.2855

Sari, T., Hasnunidah, N., Marpaung, R. R. T., Biologi, P., Lampung, F. U., \& Soemantri, 
J. P. (2018). Pengembangan Buku Penuntun Praktikum Energi dalam Sistem Kehidupan dengan Model Argument Driven Inquiry ( ADI ). (1).

Sriatun, Ellianawati, Hardyanto, W., \& Milah, I. L. (2018). Analisis Kemampuan Berfikir Kreatif Siswa pada Praktikum Asas Black Berbasis. Jurnal Physics Communication, 2(1), 70-75.

Sugiyono. (2018). Metode Penelitian Kuantitatif Kualitatif dan R\&D. Bandung: Alfabeta.

Susantini, E., Thamrin, M., Isnawati, H., \& Lisdiana, L. (2012). Pengembangan petunjuk praktikum genetika untuk melatih keterampilan berpikir kritis. Jurnal Pendidikan IPA Indonesia, 1(2), 102-108. https://doi.org/10.15294/jpii.v1i2.2126

Suwarno, S., \& Hasanudin, S. (2020). Project-based learning Model Assisted by Worksheet: It's Effect Students Creativity and Learning Outcomes. Jurnal Pendidikan Biologi Indonesia, 6(1), 113-122.

Usman, \& Ratnasari, D. (2019). Persepsi Mahasiswa terhadap Pembelajaran yang Mengembangkan Keterampilan Berpikir Kreatif yang Diintegrasikan dengan Pembelajaran Berbasis Proyek. Jurnal Penelitian Pendidikan Biologi, 3(1), $27-35$.

Weldan N U. (2018). Pengembangan Penuntun Praktikum Pembuatan Cenil Nanas Pada Sub Materi Peran Tumbuhan Di Bidang Ekonomi. In Artikel penelitian. Pontianak: Universitas Tanjung Pura.

Yerimadesi, Bayharti, Jannah, Lufri, Festiyed, \& Kiram. (2018). Validity And Practitality Of Acid-Base Module Based On Guided Discovery Learning For Senior High School, Iop Conf. Series: Materials Scince And Engineering, 335:012097. Artikel Penelitian. 